\title{
The postgraduate students' (masters, PhD) metaphors about education of statistic
}

\author{
Serap Colak ${ }^{1 \mathrm{a}}$, Mehmet Deniz Yener $^{2}$, Enis Colak $^{3}$, Rabia Tasdemir ${ }^{2}$, Tuncay Colak ${ }^{2}$, \\ Belgin Bamac ${ }^{2}$, Murat Son $^{4}$ \\ ${ }^{1}$ Kocaeli University, School of Physical Education and Sport, Department of Sports Management, \\ Kocaeli, Turkey \\ ${ }^{2}$ Kocaeli University, School of Medicine, Department of Anatomy, Kocaeli, Turkey \\ ${ }^{3}$ Kocaeli University, School of Physical Education and Sport, Department of Recreation, Kocaeli, \\ Turkey \\ ${ }^{4}$ Kocaeli University, School of Physical Education and Sport, Department of Trainer Education, \\ Kocaeli, Turkey
}

\begin{abstract}
Statistics is an important part of our life when it comes to economy, education, sport, politics and research. Research is a primary job for the ones pursuing academic career and statistics is one of the basic components of a research. Metaphor is used as an equivalent to figurative expression ('mecaz' in Turkish language). Study group is composed of 19 females (age 27.7) and 40 males (age 30.85) - 59 students in total. Demographic information of participants was collected. Participants were provided with questionnaire in order to assess their metaphorical creation whereby they were asked to fill in the sentence - "statistics is like/ similar to ..., because..." - with metaphor. The study has collected total of 59 metaphors in 6 categories. The most created metaphor is in 'discovering/ revealing ' category. $42.5 \%$ of Master's students and $25 \%$ of $\mathrm{PhD}$ students are in this category. Metaphors created by graduate students are representing their views about statistics course and hence their view about importance of research. The category 'discovering/ revealing', the one with the most created metaphor of this study, is the main concept of science. Consequently, good knowledge of statistics is needed for graduate students to conduct research.
\end{abstract}

Keywords: Statistics, education, methaphor, masters.

\section{Introduction}

Analogy is a way of comparing two distinct classes and claiming what is said about one can be said about the other based on their similarity or similarities. The aim is to make the understanding of unknown easier by likening it to the known. Analogical learning

\footnotetext{
${ }^{a}$ Corresponding author: srpclk@gmail.com
} 
methodology is formed by means of conceptual similarities. In this respect, metaphor can be defined as functional analogy. Given it has at least two meanings; with a broader meaning it is closer to figurative speech, with more strict meaning it is closer to definition [11].

In our country metaphor is used as an equivalent to 'mecaz' (figurative expression). The word has roots in ancient languages with meaning of transfer/ carrying over. Aristotle has used metaphor in his works and considered metaphor as a pleasant way of learning. Nowadays, research is being done about the usage of metaphors as a learning methodology. By using metaphor individuals are transferring their views about occasion, phenomenon or notion. Similarities between two objects are serving as foundation for this type of expression. So the meaning is transferred to the other side as an abstract expression. Metaphor, as a way of communication and description method, is frequently, yet often times without being fully appreciated, used in understanding the world we live in, in expressing ourselves within a society and in transferring our thoughts in a different way while having reciprocal dialogues [5]. Metaphor is a powerful cognitive tool which shapes, directs and controls our ideas about phenomena, without us being conscious of it. This communication method is finding its way into research domain within fields such as education and related scientific fields [13].

The aim of this study is to determine and compare metaphors created by Master's and $\mathrm{PhD}$ students about statistics course, which has an important role in a postgraduate education.

\section{Method}

\subsection{Working group}

This study has voluntary participants of 64 Master's and PhD students, studying at Kocaeli University, Institute of Health Sciences. Students were asked about their major, study level, age, sex, geographical region they are coming from and their current region of residence. $79.6 \%$ of participants are Master`s degree students whereas $20.3 \%$ are $\mathrm{PhD}$ students. $32.2 \%$ are females and $67.9 \%$ are males. During the study they were asked to create metaphors while expressing their views about statistics.

\subsection{Data collection}

Brief definition of metaphor and an example was provided in order to help participants to create metaphors. Participants were handed with forms where they were asked to fill in the sentence - "statistics is like/ similar to ..., because..." - with metaphor. For us to better understand the metaphor and to be able to separate them into distinct categories sentence was constructed with 'because' clause, whereby they had to provide the reasoning behind the metaphor [2].

\subsection{Analysis of data}

Metaphors, created by 64 students of Institute of Health Sciences, were analyzed and interpreted in three steps [15].

1. Identification and filtering criteria for metaphors: metaphors were analyzed for their being stated clearly. At the same time, the ones with no clear connection of source with target and the ones with inappropriate usage or not used at all $(\mathrm{n}=5)$ were eliminated and 59 metaphors were left. 
2. Classification of metaphors: metaphors were divided into 6 categories: 1 . Disappearing/Unknown situation, 2. Desperate challenge, 3. Bitterness/Pleasure, 4. Discovering/ revealing, 5. Guidance/ investment to the knowledge, 6. Finding a solution to a problem [1].

3. Validity and confidence: several papers were considered [1,2] while putting metaphors into distinct categories. Metaphors not fitting into consensus categories, fitting into two distinct categories or sentences not containing metaphors were excluded $(n=5)$.

Results obtained after comparison were tested for confidence by formula, defined by Miles and Huberman - 'Confidence $=$ Agreement/ Agreement + Disagreement x 100'. In a qualitative research consensus in results of evaluations among experts and researchers should be at least $90 \%$. This study has confidence of $0.92(59 / 59+5)$.

\section{Results}

Within 6 categories total of 59 metaphors and their reasonings were collected from participants. Mean age of participants is 28.7. All of 47 Master's and $12 \mathrm{PhD}$ students are residing in flats. The most produced metaphor for the word 'statistics' is making up 38.9\% and corresponds to Discovering/ revealing category. Metaphors within other categories are as following: 'Disappearing/Unknown situation' $(n=6)$, 'Desperate challenge' $(n=2)$, 'Bitterness/Pleasure' $(\mathrm{n}=9)$, 'Discovering/ revealing' $(\mathrm{n}=23)$, 'Guidance/ investment to the knowledge' $(n=8)$, 'Finding a solution to a problem' $(n=11)$. Distribution of metaphors according to their respective categories is given in table 1 [1].

Table 1. Metaphor categories and distribution.

\begin{tabular}{|c|c|c|}
\hline $\begin{array}{l}\text { Metaphor categories } \\
(\mathbf{n}=6)\end{array}$ & $\begin{array}{l}\text { Frequency } \\
(\mathbf{n}=\mathbf{5 9})\end{array}$ & Metaphors \\
\hline $\begin{array}{l}\text { Disappearing/Unknown } \\
\text { situation }\end{array}$ & $\begin{array}{l}\% 10,1 \\
(n=6)\end{array}$ & $\begin{array}{l}\text { Curtain (1), Labyrinth (1), Complexity (1), Obscurity (1), } \\
\text { Suffocation (1), Tangle (1). }\end{array}$ \\
\hline 2. Desperate challenge & $\% 3,3(n=2)$ & Money counting machine (1), Space (1). \\
\hline 3. Bitterness/Pleasure & $\begin{array}{l}\% 15,2 \\
(n=9)\end{array}$ & $\begin{array}{l}\text { Life (2), Skirt (2), İstanbul (1), Soup (1), Water (1), Donkey (1), } \\
\text { Pulmonary thrombus (1). }\end{array}$ \\
\hline $\begin{array}{l}\text { 4. Discovering/ } \\
\text { revealing }\end{array}$ & $\begin{array}{l}\% 38,9 \\
(n=23)\end{array}$ & $\begin{array}{l}\text { Crossword (5), Math (4), Computer (2), Mirror (2), Game (2), } \\
\text { Knitting (1), Water ball (1), Carry rice (1), Painting (1), Hill (1), } \\
\text { Living (1), Microscope (1), Dragon (1). }\end{array}$ \\
\hline $\begin{array}{l}\text { 5. Guidance/ } \\
\text { investment to the } \\
\text { knowledge }\end{array}$ & $\begin{array}{l}\% 13,5 \\
(\mathrm{n}=8)\end{array}$ & $\begin{array}{l}\text { Compass (1), Science (1), Bookshelf (1), Programming (1), Way } \\
\text { (1), Road map (1), consensus (1), Driver (1). }\end{array}$ \\
\hline $\begin{array}{l}\text { 6. Finding a solution to } \\
\text { a problem }\end{array}$ & $\begin{array}{l}\% 18,6 \\
(n=11)\end{array}$ & $\begin{array}{l}\text { Digital data (1), Base (1), Team work (1), Addition (1), Make-up } \\
\text { (1), İterpretation(1), Clew (1), Solving(1), Achieving results (1), } \\
\text { Straight (1), Calculator(1). }\end{array}$ \\
\hline
\end{tabular}

The most produced metaphor is falling into the category ' Discovering/ revealing making up 38.9\% of all metaphors produced and this category goes in parallel with the aim of statistics. The most used metaphor within this category is 'puzzle' $(n=5)$. It also can be said that puzzle is associated with statistics by having meanings of discovering and revealing.

The most created metaphor, when sex of participants are taken into account, belongs to ' Discovering/ revealing ' (with 37.5\% $(n=15)$ of females and $42.1 \%(n=8)$ of males falling into this category). Values within other categories when sex is taken into accounted are provided in table 2 . 
Table 2. Metaphor category analysis by gender.

\begin{tabular}{lcc}
\hline \multirow{2}{*}{ Metaphor categories } & \multicolumn{2}{c}{ The number and percentage of gender } \\
\cline { 2 - 3 } & Woman: \%32,2 N=19 & Man: \%67,8 N:40 \\
\hline Disappearing/Unknown situation & $\% 10,5 \mathrm{n}=2$ & $\% 10 \mathrm{n}=4$ \\
Desperate challenge & --- & $\% 5 \mathrm{n}=2$ \\
Bitterness/Pleasure & $\% 10,5 \mathrm{n}=2$ & $\% 17,5 \mathrm{n}=7$ \\
Discovering/ revealing & $\% 42,1 \mathrm{n}=8$ & $\% 37,5 \mathrm{n}=15$ \\
Guidance/ investment to the knowledge & $\% 10,5 \mathrm{n}=2$ & $\% 15 \mathrm{n}=6$ \\
Finding a solution to a problem & $\% 26,3 \mathrm{n}=5$ & $\% 15 \mathrm{n}=6$ \\
\hline
\end{tabular}

Metaphor frequencies in category ' Discovering/ revealing 'showed differences when it was evaluated according to groups of Master`s and $\mathrm{PhD}$ students. $42.5 \%$ of Master`s student had metaphors within this category whereas lower frequency - $25 \%$ - of $\mathrm{PhD}$ students have produced metaphors in same category. Total count of participants is 59 and $23(38.9 \%)$ of them fall into this category.

Besides, none of $\mathrm{PhD}$ students has created metaphors in 'Guidance/ investment to the knowledge` category.

Table 3. Metaphor category distribution of master's and doctoral students.

\begin{tabular}{lcc}
\hline \multirow{2}{*}{ Metaphor categories } & \multicolumn{2}{c}{ Distribution of master's and doctoral students } \\
\cline { 2 - 3 } & Master: \%79,6 N=47 & PhD: \%20,4 N:12 \\
\hline Disappearing/Unknown situation & $\% 10,6 \mathrm{n}=5$ & $\% 8,3 \mathrm{n}=1$ \\
Desperate challenge & $\% 2.1 \mathrm{n}=1$ & $\% 8,3 \mathrm{n}=1$ \\
Bitterness/Pleasure & $\% 10,6 \mathrm{n}=5$ & $\% 33 \mathrm{n}=4$ \\
Discovering/ revealing & $\% 42,5 \mathrm{n}=20$ & $\% 25 \mathrm{n}=3$ \\
Guidance/ investment to the knowledge & $\% 17, \mathrm{n}=8$ & --- \\
Finding a solution to a problem & $\% 17 \mathrm{n}=8$ & $\% 25 \mathrm{n}=3$ \\
\hline
\end{tabular}

When age is taken into account, 'Guidance/ investment to the knowledge category has the lowest mean age whereas 'Desperate challenge' category has the highest mean age.

Table 4. The average age by category.

\begin{tabular}{lcc}
\hline Metaphor categories & Frequency $(\mathbf{n})$ & Mean age \\
\hline Disappearing/Unknown situation & $\% 10,1(\mathrm{n}=6)$ & 31 \\
Desperate challenge & $\% 3,3(\mathrm{n}=2)$ & 34 \\
Bitterness/Pleasure & $\% 15,2(\mathrm{n}=9)$ & 28,2 \\
Discovering/ revealing & $\% 38,9(\mathrm{n}=23)$ & 28,6 \\
Guidance/ investment to the knowledge & $\% 13,5(\mathrm{n}=8)$ & 25,9 \\
Finding a solution to a problem & $\% 18,6(\mathrm{n}=11)$ & 29,6 \\
\hline
\end{tabular}

\section{Discussion}

Metaphor, has taken its origin from Greek word 'metapherein' [14]. Actually, metaphor consists of two words - Meta (to change) and -Pherein (to bear) [10].

Researches have been conducted with students and other occupation groups on the usage of metaphors in education [2,3,6,8,12,14]. Kalyoncu [9] has studied with Arts teacher candidates on metaphors in concept of teaching and art education. Besides, similar metaphor related works have been done with primary school teacher candidates and on programs concerning postgraduate education [4,7]. In this respect, we have studied metaphors created by postgraduate students about statistics course, which has an important role in postgraduate education.

Statistics metaphors, created by 2015-2016 students of Institute of Health Sciences consisting of Master's and $\mathrm{PhD}$ students (59 in total), were examined. Discrepancies in 
categorical distributions of metaphors were observed. The category ' Discovering/ revealing ' was observed as the one with the highest frequency - 38.9\% $(n=23)-$ of created metaphors. This category contains metaphors created by $42.5 \%$ of Master's students and $25 \%$ of PhD students. This shows that the way of likening statistics to the notion of discovering was used more frequently by Master's students. Same phenomenon was not seen when different categories were examined by taking into account ages of participants. The category of 'Discovering/ revealing' is closely related to the purpose of statistics and discrepancies of metaphor frequencies in two study levels reflects the views of respective participants about this subject. We think that studies looking for similar discrepancies will help the researcher to reflect upon statistics or some other target phenomenon.

\section{References}

1. Aktekin, M., Aktekin, NC. Anatomi öğrenmenin kaçınılmaz acısı. XIIIth National Congress of Anatomy with International participation, Kyrenia, Turkish Republic of Northern Cyprus, 28th October-1st November, 2. 2010.

2. Colak, S. Metaphoric Perceptions Of Physical Education And Sports Students To The Concept Computers Education. INTE 2014, International Conference On New Horizons In Education. Paris, France, 25-27, June 2014.

3. Döș, İ. Aday öğretmenlerin müfettişlik kavramına ilişkin metafor algıları. Gaziantep Üniversitesi Sosyal Bilimler Dergisi. 9(3), 607-629 (2010)

4. Dündar, H., Karaca, E.T. Pedagogical formation students conceptual metaphors about pedagogical formation program. Gazi Üniversitesi Endüstriyel Sanatlar Eğitim Fakültesi Dergisi. 30, 19-34 (2013).

5. Eraslan L. Sosyolojik Metaforlar. Akademik Bakış Dergis.27, 1-22 (2011).

6. Gillis, C., Johnson, C. L. Metaphor as renewal: Re-imagining our Professional selves. English Journal, 91(6), 37-43 (2002).

7. Gültekin, $M$. The metaphors that primary education teacher candidates use regarding curriculum. Education and Science. 38(169), 126-141 (2013).

8. Kalyoncu, R. Visual arts teacher candidates metaphors related to concept of teaching. Mustafa Kemal University Journal of Social Sciences Institute. 9(20), 474-484 (2012).

9. Kalyoncu, R. Sınıf öğretmeni adaylarının sanat eğitimi dersi kavramına ilişkin metaforlar1. Karadeniz Teknik Üniversitesi Journal of New World Sciences Academy. 8(1), 90-102 (2012).

10. Levine, P. M. Metaphors and images of classrooms. Kappa Delta Pi Record, Summer. 172-175. (2005).

11. Mason L. Cognitive and Metacognitive aspects in Conceptual Change by analogy. Instructional Science. 22, 157-187 (1994).

12. Öztürk, C. Sosyal bilgiler, sınıf ve fen bilgisi öğretmen adaylarının coğrafya kavramına yönelik metafor durumları. Kırşehir Eğitim Fakültesi Dergisi. 8(2), 55-69 (2007).

13. Saban, A. Öğretmen adaylarının öğrenci kavramına ilişkin sahip oldukları zihinsel imgeler. Türk Eğitim Bilimleri Dergisi, 7(2), 281-326 (2009).

14. Soysal, D., Afacan, O. Metaphors used by primary school students to describe 'Science and technology lesson' and 'Science and technology teacher'. Mustafa Kemal University Journal of Social Sciences Institute. 9(19), 287-306 (2012).

15. Şehnaz Y. WELLS. A Study of Trainee Visual Arts Teachers Metaphorical Perception of the Concept of 'The Teacher' and 'The Artist'. Hacettepe University Journal of Education 30(3), 160-175 (2015). 